\title{
ANALYSIS OF TECHNOLOGIES FOR SPACECRAFT REMOVAL FROM LOW EARTH ORBITS USING ONBOARD-PRODUCED ELECTROMAGNETIC AND MAGNETIC FIELDS
}

\author{
Institute of Technical Mechanics \\ of the National Academy of Sciences of Ukraine and the State Space Agency of Ukraine, \\ 15 Leshko-Popelya St., Dnipro 49600,Ukraine; e-mail: Ernando@i.ua
}

\begin{abstract}
The aim of this paper is to analyze the effectiveness of propulsion devices with permanent magnets as an alternative space debris deorbit system for low earth orbits.

The paper considers current problems in the development of methods and means for deorbiting used spacecraft with the help of electromagnetic and magnetic fields produced by different onboard magnetic devices and overviews state-of-the art spacecraft deorbit systems that use an onboard-produced electromagnetic field whose interaction with the incident flow of the ionospheric plasma and the Earth's magnetic field produces an additional drag force, thus deorbiting the spacecraft. The advantages and disadvantages of electromagnetic spacecraft propulsion systems are identified. An alternative method and system are proposed for deorbiting space debris objects using permanent-magnet propulsion devices. A construction diagram of a permanent-magnet device is presented, and an algorithm of its operation is proposed. Magnetic and electromagnetic field shields were analyzed, and the most appropriate shielding material was chosen: a multilayer shield that consists of aluminum, copper, and magnetic layers. A mathematical model of the orbital motion of a spacecraft with the permanent-magnet device was developed. Using SciLab, the deorbit time was calculated for different spacecraft and different altitudes. From the calculated results it was concluded that the effectiveness of the magnet-produced drag force depends on the relation between the spacecraft's inertial characteristics and the permanent magnet volume. It was found that permanent-magnet propulsion devices as deorbit systems are ineffective for large spacecraft heavier than $2 \mathrm{t}$. This is due to the fact that the increase in the magnet-produced drag force with the permanent magnet volume is not in proportion to the increase in the spacecraft's inertial characteristics with the spacecraft mass. Using these results, the range of effective use of permanent-magnet propulsion device was determined.
\end{abstract}

Keywords permanent magnets, spacecraft, deorbit system, magnetic field, electromagnetic field, electric field, ionospheric plasma flow.

1. The Orbital Debris Quarterly News. NASA JSC Houston. 2018. Issue 2. V. 22. P. 8

2. Christophe Bonnal, Jean-Marc Ruault, Marie-Christine Desjean. Active debris removal: Recent progress and current trends. Acta Astronautica. 2013. V. 85, Pp. $51-60$.

3. The clean space blog. European Space Agency. 2018. URL: http://blogs.esa.int/cleanspace/2018/04/27/activedebris-removal-to-enable-space-servicing-vehicles (last accessed Sept. 3, 2018).

4. Paliy A. S. Spacecraft deorbit methods and means (state of the art) (in Russian). Teh. Meh. 2012. No. 1. Pp. 94 $-102$.

5. Paliy A. S., Skorik A. D. Analysis of use of aerodynamic systems to deorbit modular large-sized space objects from low near-earth orbits (in Russian). Teh. Meh. 2014. No. 2. Pp. 43 - 51.

6. Winglee R.M., Slough J., Ziemba T., Goodson A. Mini-Magnetospheric Propulsion: Tapping the energy of the solar wind for spacecraft propulsion. Journal of Geophysical Research. 2000. V. 105. No. A9. Pp. 21067 21077.

7. Ikkoh Funaki, Hiroshi Yamakawa. Solar Wind Sails, Exploring the Solar Wind, Dr. Marian Lazar (Ed.). ISBN: 978-953-51-0339-4. InTech. 2012. Pp. 439 - 463. URL: https://www.intechopen.com/books/exploring-thesolar-wind/solar-wind-sails (last accessed Sept. 3, 2018).

8. Hoyt R., Forward R. Performance of the Terminator Tether for Autonomous Deorbit of LEO Spacecraft. AIAA99-2839 35-th Join Propulsion Conference \& Exhibit. 20 - 24 June. Los Angeles. 1999. Pp. 1 - 10.

9. Hoyt R., Forward R. Application of the terminator tether ${ }^{\mathrm{TM}}$ electrodynamic drag technology to the deorbit of constellation spacecraft. American Institute of Aeronautics and Astronautics Inc. 1998. Pp. 1 - 19. URL: http://www.tethers.com/papers/TTPaper.pdf (last accessed Sept. 3, 2018).

10. Carmen Pardini, Toshiya Hanada, Paula H. Krisko. Benefits and Risks of using electrodynamic tethers to deorbit spacecraft. IAC-06-B6.2.10. URL: https://www.iadc-online.org/Documents/IADC-06-08.pdf (last accessed Sept. 3, 2018).

11. Yasumasa Ashida. Study on propulsive characteristics of magnetic sail and magneto plasma sail by plasma particle simulations: PhD dissertation. Kioto. 2014. Pp. 7 - 50. URL: https://repository.kulib.kyotou.ac.jp/dspace/bitstream/2433/185206/2/dkogk03813.pdf (last accessed Sept. 3, 2018).

12. Shuvalov V. A., Kuchugurnyi Yu. P. Experimental substantiation of effectiveness of conception of artificial mini-magnetosphere as a means of spacecraft motion controlling in the Earth ionosphere (in Russian). Kosm. Mauka Tehnol. 2018. V. 24. No. 2. Pp. $43-46$. 
13. Shuvalov V. A., Gorev N. B., Tokmak N. A., Pis'menny N. I., Kochubei G. S. Control of the drag on a spacecraft in the earth's ionosphere using the spacecraft's magnetic field. Acta Astronautica. 2018. Vol. 151. Pp. $717-725$.

14. Shuvalov V. A., Tokman N. A., Pis'mennyi N. I., Kochubei G. S. Dynamic interaction of a magnetszed body with a rarefied plasma flow. Journal of Applied Mechanics and Technical Physics. 2016. V. 57. No. 1. Pp. 145 -152 .

15. Ukrainian Patent for Utility Model No. 125265, IPC B64G 1/00, B64G 1/10, B64G 1/24. Space object orbit transfer method (in Ukrainian). Shuvalov V. O., Dehtiarenko P. H., Symanov V. H., Khorolskyi P. H., Loboda P. I. u2017 09603 ; filed Oct. 2, 2017 ; published May 10, 2018.

16. Lapkhanov E. ., Paliy A. S. Current problems involving the deployment and deorbit of nano- and picosatellite constellations (in Russian). Aviatsionno-Kosmicheskaya Tekhnika i Tekhnologiya. 2018. No. 4 (148). Pp. $20-35$.

17. Lapkhanov E. O., Paliy $O$. S. Analysis of the possibility to use a propulsion system with permanent magnets for spacecraft in a near-Earth orbit (in Ukrainian). System Technologies. 2018. No. 4. P. 24 - 35.

18. Ukrainian Invention Patent Application No. 201801742, IPC B 64 G 1/62. Method for the removal of space debris objects from near-Earth space using a magnetic field produced onboard thereof (in Ukrainian) / Shuvalov V. O., Paliy O. S., Lapkhanov E. O. ; No. 201801742 ; filed Feb. 21, 2018.

19. Abasov R. K. Use of carbon materials in electromagnetic field shielding (in Russian). Polytechnical Student Journal. 2016. No. 5. Pp. 1 - 9.

20. Ostrovskij O. S., Odarenko Ye. N., Shmatko A. A. Protective shields and electromagnetic waves absorbers (in Russian). Physical Surface Engineering. 2003. V. 1. No. 2. Pp. $161-173$.

21. Safonov A. L., Safonov L.I. Electric rectangular connectors. Multilayer metallized shields for electromagnetic interference protection and methods to make them (in Russian). Technologies in Electronic Industry. 2015. No. 1. Pp. $64-69$.

22. Dmitrenko V.V., Phyo Wai Nyunt, Vlasik K.F., Grachev V.M., Grabchikov S.S., Muravyev-Smirnov S.S., Novikov A.S., Ulin S.E., Uteshev Z.M., Chernysheva I.V., Shustov A.Y. Electromagnetic shields based on multilayer film structures. Bulletin of the Lebedev Physics Institute. 2015. V. 42. No. 2. Pp. 43 - 47.

Received on September 14, 2018, in final form on December 10, 2018. 